\title{
ASSOCIATION OF ANTI-CYCLIC CITRULLINATED PEPTIDE ANTIBODY IN A SAMPLE OF ADULT PATIENTS WITH PSORIASIS AND PSORIATIC ARTHROPATHY
}

\author{
KHUDAIR AL-BEDRI ${ }^{1}$, ZAINAB A MAHMOOD ${ }^{2}$, AQEEL HUSSEIN SADEQ ${ }^{3 *}$
}

${ }^{1}$ Department of Medicine, Consultant Internist and Rheumatologist, College of Medicine, University of Baghdad, Baghdad, Iraq. ${ }^{2}$ Department of Medicine, College of Medicine, University of Basra, Basra, Iraq. ${ }^{3}$ Department of Rheumatology, Baghdad Teaching Hospital, Rheumatology Unit, Baghdad, Iraq. Email: akeelhussein@yahoo.com

Received: 19 July 2018, Revised and Accepted: 17 August 2018

ABSTRACT

Objective: Psoriatic arthritis (PsA) is a chronic inflammatory arthropathy commonly associated with psoriasis, a large number of patients with PsA that has persistent inflammation may develop progressive joint damage and disability and have reduced life expectancy. This study aims to determine the associations of anti-cyclic citrullinated peptide (CCP) antibodies in adult patients with psoriasis and PsA.

Methods: A case-control study was conducted at Baghdad teaching hospital, Units of Rheumatology and Dermatology, during the period from December 2016 to April 2017 including three groups; 40 patients with psoriasis, 40 patients with PsA fulfilling the CASPAR classification criteria, and 40 healthy control persons.

Results: Two patients with psoriasis (5\%) and 10 patients with PsA (25\%) were seropositive for anti-CCP antibodies (ACPA). Healthy controls were negative for anti-CCPA. Regarding ACPA positivity, a significant difference was found between those three studied groups ( $<<0.001$ ) and there was a significant difference between positive and negative ACPA in PsA patients regarding disease activity score ( $\mathrm{p}=0.044)$.

Conclusion: Positive ACPA were found more significant with PsA than in patients with psoriasis as well as associated with higher disease activity.

Keywords: Psoriasis, Psoriatic arthritis, Anti-cyclic citrullinated peptide antibodies.

(C) 2018 The Authors. Published by Innovare Academic Sciences Pvt Ltd. This is an open access article under the CC BY license (http://creativecommons. org/licenses/by/4. 0/) DOI: http://dx.doi.org/10.22159/ajpcr.2018.v11i11.28577

\section{INTRODUCTION}

Psoriatic arthritis (PsA) is a chronic inflammatory arthropathy commonly associated with psoriasis [1]. Initially, PsA was considered to be a mild, non-progressive disease compared with rheumatoid arthritis (RA). However, accumulating evidence confirms that a substantial proportion of patients with PsA has persistent inflammation, develops progressive joint damage and disability, and has reduced life expectancy [2].

Psoriasis associated with a lot of complications includes metabolic syndrome. Metabolic syndrome-induced oxidative stress may play an important role in the development of cognitive impairment, neuropathy, and depressive disorders while its effect on cell proliferation, angiogenesis, and apoptosis may contribute to the pathogenesis of colorectal cancer [3]. In addition, autonomic dysfunction may be occur with varying frequency and intensity, sympathetic nervous system dysfunction can lead to severe consequences including myocardial infarction, arrhythmias, and sudden cardiac death [4].

It equally affects men and women at the $3^{\text {rd }}-5^{\text {th }}$ decade of life $(30-50$ years), it is more common in Caucasians and has a clear genetic predisposition. It has a prevalence of $0.04-0.2 \%$, in the general population and $25-34 \%$, in patients with psoriasis [5]. Most patients (70\%) have preexisting psoriasis, but in $20 \%$ arthritis predates the occurrence of skin disease. Occasionally, arthritis and psoriasis develop synchronously [6]. Cyclic citrullinated peptide (CCP) is an artificial molecule in which two serine residues in a major epitope peptide from filaggrin is converted to cysteine, and the circular form is made by S-S disulfide bond [7]. Anti-CCP antibodies (ACPA) are autoantibodies (antibodies directed against one or more of the individuals own proteins) frequently detected in RA patients. During inflammation, citrulline is incorporated enzymatically into proteins, in a reaction which is called citrullination [8]. These autoantibodies are well known to carry a poor prognostic value in RA and because of the recently noticed aggressive behavior of PsA that tends to be similar to RA so we try to look for the factors that may cause this aggressive course.

\section{METHODS}

Study design and sample selection

A case-control study was included on 120 subjects, who attended Units of Rheumatology and Dermatology in Baghdad teaching hospital for their routine follow-up during the period from December 2016 to April 2017. The subjects were divided into three groups; 40 patients with psoriasis (positive control) whom diagnosed clinically and subdivided into three groups according to the severity of psoriasis using psoriasis area and severity index (PASI) score, 40 PsA patients fulfilling the CASPAR classification criteria for PsA [9], and 40 apparently healthy controls with age and sex matched. All patients were informed of the objectives of the study and gave verbal consent for their voluntary participation in the study. Patients with overlap with other collagen vascular diseases, hepatitis B and C, tuberculosis, and sepsis were excluded from the study.

\section{Data collection and clinical evaluation}

Data were collected using the preconstructed data collection sheet, questionnaire included demographic, clinical, and investigation data of the patients. All patients were examined concerning age, gender, family history, disease duration, a pattern of skin and joint involvement, hemoglobin, white blood cell count, platelet count, C-reactive protein (CRP), rheumatoid factor (RF), and erythrocyte sedimentation rate (ESR). All patients were graded according to the PASI score. Disease activity score (DAS) 28 was calculated using ESR for the assessment of PsA $[10,11]$. Estimation of ACPA levels by ELISA technique which is Immunoscan CCPlus ${ }^{\circledR}$ test kit (Euro Diagnostica, Sweden) used for 
qualitative and semi-quantitative determination of IgG antibodies to CCP in human sera. The assay is used to detect antibodies in a single serum specimen.

\section{Statistical analyses}

Statistical analyses were done using SPSS version 23 computer software (Statistical Package for the Social Sciences) in association with Excel version 5. Descriptive statistics for categorical variables were done using frequency and percentages. To measure the strength of association between two categorical variables, the odds ratio (OR) was used. The statistical significance of the measured OR is assessed by a special $\chi^{2}$ formula. Associations between two categorical variables were explored by cross-tabulation. The statistical significance of such associations was assessed by $\chi^{2}$ test of homogeneity or Fisher's exact test (when the conditions for a valid Chi-square test are not met). The level of statistical significance was set at $\mathrm{p}<0.05$. All analyzed tests were bilateral (two tailed).

\section{RESULTS}

Male gender was $70 \%$ in positive controls, $65 \%$ in healthy controls, and $52.5 \%$ in the cases group with no significant difference between the three study groups $(\mathrm{p}=0.25)$. The mean age was 43.7 years among cases group, 41.5 years among healthy controls, and 39.7 years in positive controls with no significant difference between groups $(p=0.48)$ (Table 1$)$.

The duration of arthropathy in cases group ranged from a few months to 25 years, with a mean duration of \pm SD of $7.5 \pm 6.5$ years. The DAS score of these cases ranged between 1.2 and 7.2 , with a mean \pm SD of $4.7 \pm 1.5$ years. In addition, polyarthritis was the most frequently observed type of arthritis, being reported in about $2^{\text {nd }}-3^{\text {rd }}$ of cases groups $(67.5 \%)$, followed by oligoarthritis (17\%), axial (8\%), and DIP (8\%) (Fig. 1).

Regarding skin pattern, plaque psoriasis was reported for all patients, no other skin pattern was reported. Regarding the PASI score, 78.75\% presented with mild disease activity, $17.5 \%$ of patients presented with moderate disease activity, and $3.75 \%$ of patients presented with severe disease activity.

As shown in Table 2, none of the healthy controls had a positive ACPA. This rate increased to $5 \%$ among patients with psoriasis and further to $25 \%$ among psoriatic arthropathy patients. The difference in a positive test between the three study groups was statistically significant. The presence of psoriatic skin lesions only increased the risk of having a positive ACPA test by 5.3 times compared to healthy controls, but the risk estimate failed to reach the level of statistical significance. The presence of arthritis in patients with psoriasis significantly increased the risk of positivity for ACPA by 6.3 times as compared to positive controls (patients with psoriasis but without arthritis) and 27.9 times as compared to healthy controls (persons who have neither psoriasis nor PsA) (Table 3).

The mean DAS 28 score was significantly higher (mean DAS score=5.5) among PsA cases with a positive ACPA compared to those with negative test (mean DAS score $=4.5$ ) (Table 4 ).

In Table 5, gender, family history of psoriasis, pattern of joint involvement, RF, and serum CRP were tested for possible association with positive ACPA. None of these explanatory variables showed an obvious or statistically significant association with positive ACPA.

As shown in Table 6, psoriasis disease activity measured by PASI score was not affected by the presence of arthritis. The mean PASI score was not significantly different between cases group with arthritis (6.6) and positive controls without arthritis (5.3).

\section{DISCUSSION}

The era for searching the associations between ACPA, psoriasis, and PsA was markedly increased in the last decade and illustrated interesting associations. In this study, $5 \%$ of patients with psoriasis had positive ACPA compared to healthy controls, but the risk estimate failed to reach the level of statistical significance $(\mathrm{p}=0.158)$. Similar results were described by Alenius et al. showed that there was $0.7 \%$ positive ACPA in psoriatic patients which were not significant also [12]. Another two studies were done by and Abdel Fattah et al. [13] and Candia et al. [14], they found that all patients had negative ACPA. ACPA was found positive in $25 \%$ among PsA patients and negative in healthy controls which were statistically significant $(\mathrm{p}<0.001)$. This is in agreement with previous studies such as Abdel Fattah et al., Candia et al., Inanc et al., Bogliolo et al., and Cruyssen et al. [13-17]. Did not find a significant difference between healthy persons and patients with PsA regarding the positivity for ACPA $[18,19]$. This contradiction may have been due to the small patients and control sizes used in their studies. This study also showed that PsA patients in comparison to patients with psoriasis have a positive ACPA with a statistically significant difference $(p=0.023)$, which was agreed with a study done by Abdel Fattah et al. $(\mathrm{p}<0.001)$ and Candia et al. $(\mathrm{p}=0.01)[13,14]$. On the other hand, other studies like Shibata

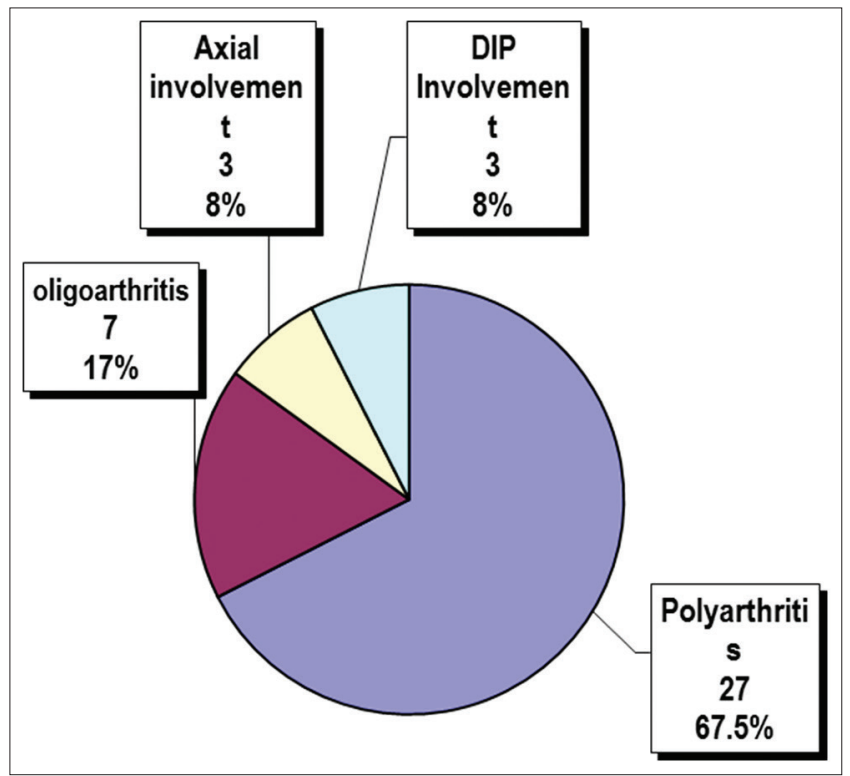

Fig. 1: The relative frequency of selected types of arthritis among cases group ( $n=40)$. DIP: Distal interphalangea

Table 1: Frequency distribution of the three study samples by gender and mean age

\begin{tabular}{lllc}
\hline Variables & $\begin{array}{l}\text { Healthy } \\
\text { controls n (\%) }\end{array}$ & $\begin{array}{l}\text { Patients with } \\
\text { psoriasis n (\%) }\end{array}$ & $\begin{array}{l}\text { Patients with } \\
\text { PsA n (\%) }\end{array}$ \\
\hline Gender & & & $0.25(\mathrm{NS})$ \\
$\quad$ Female & $14(350)$ & $12(30)$ & $19(47.5)$ \\
$\quad$ Male & $26(65.0)$ & $28(70)$ & $21(52.5)$ \\
Total & $40(100)$ & $40(100)$ & $40(100)$ \\
Age (years) & $19-73$ & $18-74)$ & $22-70$ \\
$\quad$ Range & $41.5 \pm 17.2 / 2.72$ & $39.7 \pm 13.4 / 2.12$ & $43.7 \pm 13.6 / 2.15$ \\
Mean \pm SD/SE & & & $0.48(\mathrm{NS})$ \\
\hline
\end{tabular}

NS: Not significant, p: Probability, SD: Standard deviation, SE: Standard error 
Table 2: The difference in rate of positive ACPA between the three study groups

\begin{tabular}{lllll}
\hline ACPA & $\begin{array}{l}\text { Healthy controls } \\
\mathbf{n = 4 0}(\mathbf{\%})\end{array}$ & $\begin{array}{l}\text { Patients with } \\
\text { psoriasis } \mathbf{n = 4 0}(\%)\end{array}$ & $\begin{array}{l}\text { Patients with PsA } \\
\mathbf{n = 4 0}(\mathbf{\%})\end{array}$ & p \\
\hline Positive ACPA $(>200 \mathrm{pg} / \mathrm{mL})$ & $0(0)$ & $2(5)$ & $10(25)$ & $<0.001$ \\
\hline
\end{tabular}

ACPA: Anti-cyclic citrullinated peptide antibody, PsA: Psoriatic arthritis

Table 3: Risk of having positive ACPA

\begin{tabular}{lccc}
\hline $\begin{array}{l}\text { The risk of having positive } \\
\text { ACPA for }\end{array}$ & OR & 95\% CI OR & p \\
\hline $\begin{array}{l}\text { Psoriatic patients compared to } \\
\text { healthy controls }\end{array}$ & 5.3 & $(0.52-52.7)$ & 0.158 \\
$\begin{array}{l}\text { Patients with PsA compared to } \\
\text { healthy controls }\end{array}$ & 27.9 & $(3.4-227.5)$ & 0.002 \\
$\begin{array}{l}\text { Patients with PsA compared to } \\
\text { psoriatic patients }\end{array}$ & 6.3 & $(1.29-31.1)$ & 0.023 \\
\hline
\end{tabular}

CI: Confidence interval, OR: Odds ratio

Table 4: The mean DAS 28 by ACPA among patients with PsA

\begin{tabular}{llll}
\hline DAS 28 & ACPA & p \\
\cline { 2 - 3 } & Negative & Positive & \\
\hline DAS 28 score & & & 0.044 \\
Range & $(1.2-6.7)$ & $(3.2-7.1)$ & \\
Mean \pm SD/SE & $4.5 \pm 1.4 / 0.26$ & $5.5 \pm 1.3 / 0.42$ & \\
\hline
\end{tabular}

ACPA: Anti-cyclic citrullinated peptide antibody, DAS: Disease activity score, p: Probability, SD: Standard deviation, SE: Standard error. The total number is 30 with negative and 10 with positive ACPA

et al. found that the difference was not significant between those two groups [19]. This contradiction may be due to the small size of PsA ( $n=16)$ and psoriasis $(n=15)$ patients used in their study. The presence of arthritis in addition to psoriasis significantly increased the risk of positive ACPA by 6.3 times compared to psoriasis patients and 27.9 times compared to healthy controls. To the best of our knowledge, no studies mentioned this important significant risk. There were no differences between ACPApositive and ACPA-negative PsA patients in terms of gender, age, and disease duration. The lack of this association in our study is in agreement with the results of Popescu et al., Abdel Fattah et al., and Behrens et al. $[13,20,21]$. There were no significant differences between ACPApositive and ACPA-negative PsA patients in terms of CRP, RF, and ESR also, with an agreement to the study of Popescu et al. [20]. Regarding disease activity, statistically significant difference in mean of DAS 28 score (5.5) was found in ACPA-positive patients when compared with ACPA-negative patients (4.5) ( $\mathrm{p}=0.044)$, this was in agreement with some studies such as Abdel Fattah et al., Bogliolo et al., Korendowych et al., Perez-Alamino et al., and Behren et al. $[13,15,18,21,22]$ while another study such as Alenius et al. and Cruyssen et al. disagrees with us $[12,17]$. This contradiction may have its origin in the difference in genetics and race in contradicted studied groups. Another possible issue is their use of DAS 68 score which is different DAS. Another important clinical characteristic is polyarthritis pattern which was statistically non-significant in our study, similar results were described in studies done by Korendowych et al. and Behren et al. $[18,21]$. The latter was the largest study; 1996 patients with PsA were included in the study, of which 105 patients were ACPA positive [21]. On the other hand, other studies showed an association of ACPA seropositivity with polyarthritis $[13,15,20,22,23]$. This contradiction in multiple joint patterns may have its origin in the difference of race and genetics of the contradicted study groups. Other patterns of joint involvement showed no statistically significant association with the positive ACPA. To the best of our knowledge, there were no available data showed that association.

\section{CONCLUSION}

The presence of arthritis in addition to psoriasis significantly increased the risk of positive ACPA by 6.3 times compared to psoriasis patients.
Table 5: The rate of positive ACPA by selected explanatory variables among patients with PsA

\begin{tabular}{|c|c|c|c|c|}
\hline \multirow[t]{2}{*}{ Variables } & \multicolumn{3}{|l|}{ ACPA } & \multirow[t]{2}{*}{$\mathbf{p}$} \\
\hline & $\begin{array}{l}\text { Negative } \\
\text { n (\%) }\end{array}$ & $\begin{array}{l}\text { Positive } \\
\text { n (\%) }\end{array}$ & $\begin{array}{l}\text { Total } \\
\text { n (\%) }\end{array}$ & \\
\hline Gender & & & & 1 \\
\hline Female & $14(73.7)$ & $5(26.3)$ & $19(100)$ & \\
\hline Male & $16(76.2)$ & $5(23.8)$ & $21(100)$ & \\
\hline $\begin{array}{l}\text { Family history of } \\
\text { psoriasis }\end{array}$ & & & & 0.58 \\
\hline Negative & $27(77.1)$ & $8(22.9)$ & $35(100)$ & \\
\hline Positive & $3(60)$ & $2(40)$ & $5(100)$ & \\
\hline $\begin{array}{l}\text { Pattern of joint } \\
\text { involvement }\end{array}$ & & & & 0.5 \\
\hline Polyarthritis & $19(70.4)$ & $8(29.6)$ & $27(100)$ & \\
\hline Oligoarthritis & $5(71.4)$ & $2(28.6)$ & $7(100)$ & \\
\hline Axial involvement & $3(100)$ & $0(0)$ & $3(100)$ & \\
\hline DIP involvement & $3(100)$ & $0(0)$ & $3(100)$ & \\
\hline Serum CRP (mg/dl) & & & & 0.72 \\
\hline Negative & $20(76.9)$ & $6(23.1)$ & $26(100)$ & \\
\hline Positive & $10(71.4)$ & $4(28.6)$ & $14(100)$ & \\
\hline Rheumatoid factor & & & & 0.089 \\
\hline Negative & $26(813)$ & $6(18.8)$ & $32(100.0)$ & \\
\hline Positive & $4(50.0)$ & $4(50.0)$ & $8(100.0)$ & \\
\hline
\end{tabular}

PsA: Psoriatic arthritis, CRP: C-reactive protein, ACPA: Anti-cyclic citrullinated peptide antibody, DIP: Distal interphalangeal

Table 6: The case-control difference in mean PASI score

\begin{tabular}{llll}
\hline PASI score & $\begin{array}{l}\text { Patients with } \\
\text { psoriasis }\end{array}$ & $\begin{array}{l}\text { Patients with } \\
\text { PsA }\end{array}$ & P \\
\hline $\begin{array}{l}\text { PASI score } \\
\text { Range }\end{array}$ & $(0.3$ to 23.4$)$ & $(0.2$ to 25.7$)$ & 0.3 \\
Mean \pm SD $/$ SE & $6.6 \pm 5.2 / 0.83$ & $5.3 \pm 6.3 / 1$ & \\
\hline
\end{tabular}

p: Probability, PASI: Psoriasis area and severity index, PsA: Psoriatic arthritis, SD: Standard deviation, SE: Standard error. The total number is 40 patients for both groups

Regarding disease activity, a statistically significant higher mean of DAS 28 score was found in ACPA-positive patients when compared with ACPA-negative patients.

\section{FUNDING}

This research received no grant from any funding agency in the public, commercial, or not-for-profit sectors.

\section{AUTHORS' CONTRIBUTIONS}

We declare that all of the authors of this article have contributed since the beginning of the study process until the submission process of this article.

\section{DISCLOSURE}

The authors declare that there are no conflicts of interest.

\section{REFERENCES}

1. Chimenti MS, Ballanti E, Perricone C, Cipriani P, Giacomelli R, Perricone R, et al. Immunomodulation in psoriatic arthritis: Focus on cellular and molecular pathways. Autoimmun Rev 2013;12:599-606.

2. Gladman DD, Stafford-Brady F, Chang CH, Lewandowski K, Russell ML. Longitudinal study of clinical and radiological progression 
in psoriatic arthritis. J Rheumatol 1990;17:809-12.

3. Nerkar D, Mukherjee A, Mehta BK, Banerjee S. Metabolic syndrome associated complications. Int J Pharm Pharm Sci 2015;7:22-5.

4. Syngle A, Verma I, Kaur S, Syngle T. Interleukin-17inhibition with secukinumab improves sudomotor dysfunction in psoriatic arthritis. Int J Pharm Pharm Sci 2018;10:169.

5. Kleinert S, Feuchtenberger M, Kneitz C, Tony HP. Psoriatic arthritis: Clinical spectrum and diagnostic procedures. Clin Dermatol 2007:25:519-23.

6. Ralston SH, McInnes IB. Rheumatology and bone disease. In: Walker BR, Colledge NR, Ralston SH, Penman ID, editors. Davidsons Principles \& Practice of Medicine. 22 ${ }^{\text {nd }}$ ed. London: Chrchill Livingstone; 2014. p. 1108

7. Schellekens GA, Visser H, de Jong BA, van den Hoogen FH, Hazes JM, Breedveld FC, et al. The diagnostic properties of rheumatoid arthritis antibodies recognizing a cyclic citrullinated peptide. Arthritis Rheum 2000;43:155-63.

8. Schellekens GA, de Jong BA, van den Hoogen FH, van de Putte LB, van Venrooij WJ. Citrulline is an essential constituent of antigenic determinants recognized by rheumatoid arthritis-specific autoantibodies. J Clin Invest 1998;101:273-81.

9. Taylor W, Gladman D, Helliwell P, Marchesoni A, Mease P, Mielants $\mathrm{H}$, et al. Classification criteria for psoriatic arthritis: Development of new criteria from a large international study. Arthritis Rheum 2006;54:2665-73.

10. Alitaha D, Smolen JS. Evaluation and outcomes of patients with rheumatoid arthritis. In: Hochberg MC, Silman AJ, Smolen JS, Weinblatt ME, Weisman MH, editors. Rheumatology. $4^{\text {th }}$ ed. Philadelphia, USA: Mosby Elsevier; 2011. p. 945-53.

11. Prevoo ML, Van't Hof MA, Kuper HH, van Leeuwen MA, van de Putte LB, van Riel PL. Modified disease activity scores that include twenty -eight joint counts. Development and validation in a prospective longitudinal study of patients with rheumatoid arthritis. ArthritisRheum 1995;38:44-8.

12. Alenius GM, Berglin E, Rantapää Dahlqvist S. Antibodies against cyclic citrullinated peptide (CCP) in psoriatic patients with or without joint inflammation. Ann Rheum Dis 2006;65:398-400.
13. Abdel Fattah NS, Hassan HE, Galal ZA, El Okda el SE. Assessment of anti-cyclic citrullinated peptide in psoriatic arthritis. BMC Res Notes 2009;2:44.

14. Candia L, Marquez J, Gonzalez C, Santos AM, Londoño J, Valle R, et al. Low frequency of anticyclic citrullinated peptide antibodies in psoriatic arthritis but not in cutaneous psoriasis. J Clin Rheumatol 2006;12:226-9.

15. Bogliolo L, Alpini C, Caporali R, Scirè CA, Moratti R, Montecucco C, et al. Antibodies to cyclic citrullinated peptides in psoriatic arthritis. J Rheumatol 2005;32:511-5.

16. Inanc N, Dalkilic E, Kamali S, Kasapoglu-Günal E, Elbir Y, Direskeneli $\mathrm{H}$, et al. Anti-CCP antibodies in rheumatoid arthritis and psoriatic arthritis. Clin Rheumatol 2007;26:17-23.

17. Vander Cruyssen B, Hoffman IE, Zmierczak H, Van den Berghe M, Kruithof E, De Rycke L, et al. Anti-citrullinated peptide antibodies may occur in patients with psoriatic arthritis. Ann Rheum Dis 2005;64:1145-9.

18. Korendowych E, Owen P, Ravindran J, Carmichael C, McHugh N. The clinical and genetic associations of anti-cyclic citrullinated peptide antibodies in psoriatic arthritis. Rheumatology (Oxford) 2005;44:1056-60.

19. Shibata S, Tada Y, Komine M, Hattori N, Osame S, Kanda N, et al. Anti-cyclic citrullinated peptide antibodies and IL-23p19 in psoriatic arthritis. J Dermatol Sci 2009;53:34-9.

20. Popescu C, Zofotă S, Bojincă V, Ionescu R. Anti-cyclic citrullinated peptide antibodies in psoriatic arthritis-cross-sectional study and literature review. J Med Life 2013;6:376-82.

21. Behrens F, Koehm M, Thaçi D, Gnann H, Greger G, Maria Wittig B, et al. Anti-citrullinated protein antibodies are linked to erosive disease in an observational study of patients with psoriatic arthritis. Rheumatology (Oxford) 2016;55:1791-5.

22. Perez-Alamino R, Garcia-Valladares I, Cuchacovich R, IglesiasGamarra A, Espinoza LR. Are anti-CCP antibodies in psoriatic arthritis patients a biomarker of erosive disease? Rheumatol Int 2014;34:1211-6.

23. Maejima H, Aki R, Watarai A, Shirai K, Hamada Y, Katsuoka K, et al. Antibodies against cyclic citrullinated peptide in Japanese psoriatic arthritis patients. J Dermatol 2010;37:339-45. 